\title{
Let Others Go First: How Pitch Order Affects Investor Interest in Elevator
}

Pitches

\author{
David Clingingsmith $^{1 \%}$, Scott Shane ${ }^{19 *}$
}

September 2017

\begin{abstract}
The start-ups with the most potential to innovate and generate employment are the ones most likely to rely on capital provided by outside investors. Several institutional developments including the rise of business accelerators, angel groups, and startup competitions, have meant that founders seeking this type of capital increasingly pitch their business ideas to investors in group settings, raising the question of whether the order in which ideas are pitched affects outcomes. Research on order effects in other competitive environments indicates that judges often have high expectations and calibrate their evaluations to the lower average performance of competitors at the beginning of competition, making it difficult for those going early to do as well as those performing later. We test empirically whether this calibration effect is also present for efforts by founders to pitch investors by conducting a field experiment. Entrepreneurs participating in elevator pitch competitions were randomly assigned the position in which they pitched. We find evidence of this calibration effect: investor-judges expressed substantially lesser interest in pursuing investment in the first and second ventures pitched to them.
\end{abstract}

Keywords: pitching, order effects, field experiment, entrepreneurship

\footnotetext{
${ }^{1}$ Department of Economics, Case Western Reserve University, Cleveland, Ohio.

* Corresponding author: sas46@case.edu.

The authors would like to thank Richard Boyatzis, Frederic Delmar, Jon Eckhardt, Tony Jack, and Nicos Nicolaou for their helpful comments on an earlier draft of this paper. A grant from the Burton D. Morgan Foundation funded the collection of the data used in this paper.
} 


\section{Introduction}

With the rise in pitch competitions, start-up accelerators, and angel groups, entrepreneurs increasingly seek to raise money by pitching their business ideas to investors in settings where others are also pitching the same people. For example, well-known companies such as Airbnb, Credit Karma, Dropbox, Rent-the-Runway, and Twilio all pitched investors in this setting.

Group pitch settings raise an important tactical question for entrepreneurs seeking financing at these events: "Should I try to pitch first, last or in the middle?" For event organizers, a corollary question has emerged: "What's the fairest way to order presenters?"

The order in which a founder pitches investors in a group setting is likely to affect the interest of financiers in investigating an investment in a company. Researchers studying order effects in other settings have formulated theories for why different positions in the order affect outcomes and empirical research has demonstrated that order affects outcomes in a wide range of settings, including music competitions (Flores \& Ginsburgh, 1996; Ginsburgh \& Van Ours, 2003; Bruine de Bruine \& Keren, 2003), elections (Miller \& Krosnick, 1998), athletics (Wilson, 1977), sales efforts (Wagner \& Klein, 2007), scientific research (Feenberg et al, 2015; Berger, 2016), and judicial proceedings (Kerstholt \& Jackson, 1998; Danziger, Levav, \& Avnaim-Pesso, 2011).

However, the optimal position in the order for entrepreneurs pitching investors remains unknown for two reasons. First, prior research disagrees about the optimal position. Some studies suggest that entrepreneurs would be better off pitching earlier because evaluators pay more attention to information that is provided first (Miller \& Krosnick, 1998; Feenberg et al, 2015; Berger, 2016; Mantonakis et al, 2009; Karlsson, Massa, \& Simonov, 2006; Einay \& Yariv, 2006; Shah, 2014), because judges become harsher over time (Feenberg et al, 2015; Danziger, Levav, \& Avnaim-Pesso, 2011), or because evaluators "satisfice" and choose the first acceptable alternative 
(Feenberg et al, 2015; Karlsson, Massa, \& Simonov, 2006; Haque \& Ginsparg, 2009; Huang, 2014). Other studies suggest that entrepreneurs would be better off pitching later because evaluators pay more attention to information that was more recently made available (Feenberg et al, 2015), because judges find it difficult initially to calibrate performance and are thus too harsh in the beginning (Moore, 1999), or because participants' motivation is enhanced by watching others participate first (Bruine de Bruine \& Keren, 2003).

Second, pitching investors differs in several key ways from other settings in which order matters. In investor pitches, evaluations are not directly competing. Evaluators can score all presentations equally high, and indicate that they like all presentations if that is their judgment. Further, evaluators usually assess each pitch in turn rather than assessing all at the end. Finally, the role of order in evaluation may vary by the material being evaluated, and we lack any knowledge about the role order plays in evaluating investment opportunities.

We study order effects in efforts to pitch new venture ideas to investors by conducting a field experiment. We randomly assigned the order in which 271 aspiring entrepreneurs pitched for prize money at four pitch competitions conducted in the fall of 2015. The participants delivered 90-second elevator pitches to panels of judges drawn from the local population of accredited investors. ${ }^{1}$ The judges' collective evaluation determined whether participants would pitch again in a final round for prize money.

Our randomized experiment shows that the order in which pitches occur does matter for investors' interest in financing new businesses. We find that pitching in the first or second position

\footnotetext{
${ }^{1}$ The Securities and Exchange Commission (SEC) defines an accredited investor as an individual with a net worth of at least $\$ 1$ million excluding his or her home or a single person with an annual income of at least $\$ 200,000$ in each of the past three years or a married couple with an annual income of at least $\$ 300,000$ in each of the past three years. The SEC defines an organization as an accredited investor if it is a bank, savings and loan association, broker dealer, insurance company, investment company, or private business development company.
} 
is disadvantageous because judges start with overly high expectations and must initially calibrate to the quality of the participant pool.

Section 2 presents the competing theoretical explanations for the effect of pitch order on investor interest in new ventures. Section 3 discusses the design of our experiment and the methods we use to analyze it. Section 4 presents the results of the experiment. Section 5 concludes with a discussion.

\section{Theory Development and Hypotheses}

Researchers have found that when people are evaluated in competitive settings, the order in which they appear affects the outcome (Bruine de Bruine, 2005). In step-by-step evaluations, where judges evaluate each participant after he or she has performed, researchers have developed several alternative explanations for the best position in the order from the perspective of the participant being evaluated. The "go early" argument holds that evaluations decline as the order progresses, suggesting that participants benefit from having earlier positions in the order. The "go late" argument holds that evaluations increase with as the order progresses, suggesting that participants will benefit from having later positions in the order. The "calibration up" argument holds that judges have high expectations and make low initial evaluations that they increase after the first few participants as judges calibrate their evaluation to the quality of the participant. The calibration up argument suggests that participants will benefit from avoiding the initial positions in the order. The "calibration down" argument holds that judges have low expectations and make high initial evaluations that lower increase after the first few participants as judges calibrate their evaluation to the quality of the participant. The calibration down argument suggests that 
participants will benefit from being in the initial positions in the order. Figure 1 provides an illustration of how mean evaluation changes with position in the order under the four explanations.

Theory suggests that all four explanations could plausibly affect performance in venture finance pitch competitions. However, to date we have no empirical evidence to assess the accuracy of different arguments. In this section, we present the arguments for four alternative hypotheses for the best position in the order for founders pitching investors in competitive settings drawn from the literature on serial position in other competitive settings.

\section{The "go early" argument}

The first hypothesis that emerges from research on the effect of order in competitive settings suggests that investor interest in further investigation of founder pitches should be a decreasing function of position in the order. First, some studies suggest that entrepreneurs would be better off pitching earlier because evaluators pay more attention to information that is provided first (Miller \& Krosnick, 1998; Feenberg et al, 2015; Berger, 2016; Mantonakis et al, 2009; Karlsson, Massa, \& Simonov, 2006; Einay \& Yariv, 2006; Shah, 2014). The tendency to provide more attention to information makes it easier for entrepreneurs to capture the interest of potential investors. Second, making repeated judgments in a sequence can deplete an individual's executive decision and mental resources. As a result, over time, decision makers become fatigued and tend toward acceptance of the default decision (Danzinger et al, 2011), which, in this case, is negative. ${ }^{2}$ Third, human beings tend to display a decline in attention over time and tend to lose interest in

\footnotetext{
${ }^{2}$ In this setting, the default outcome is negative. Investors finance a very small portion of businesses presented to them, with empirical evidence showing that angel investors back one in 50 ventures they have the opportunity to finance and venture capitalists funding one in 100 businesses (Rose, 2014). Because the odds are low that an investor will ultimately invest in a new company, financiers tend not to pursue investigation of most businesses pitched to them (Maxwell et al, 2011)
} 
Figure 1: Four Hypotheses about the Effects of Order on Evaluation

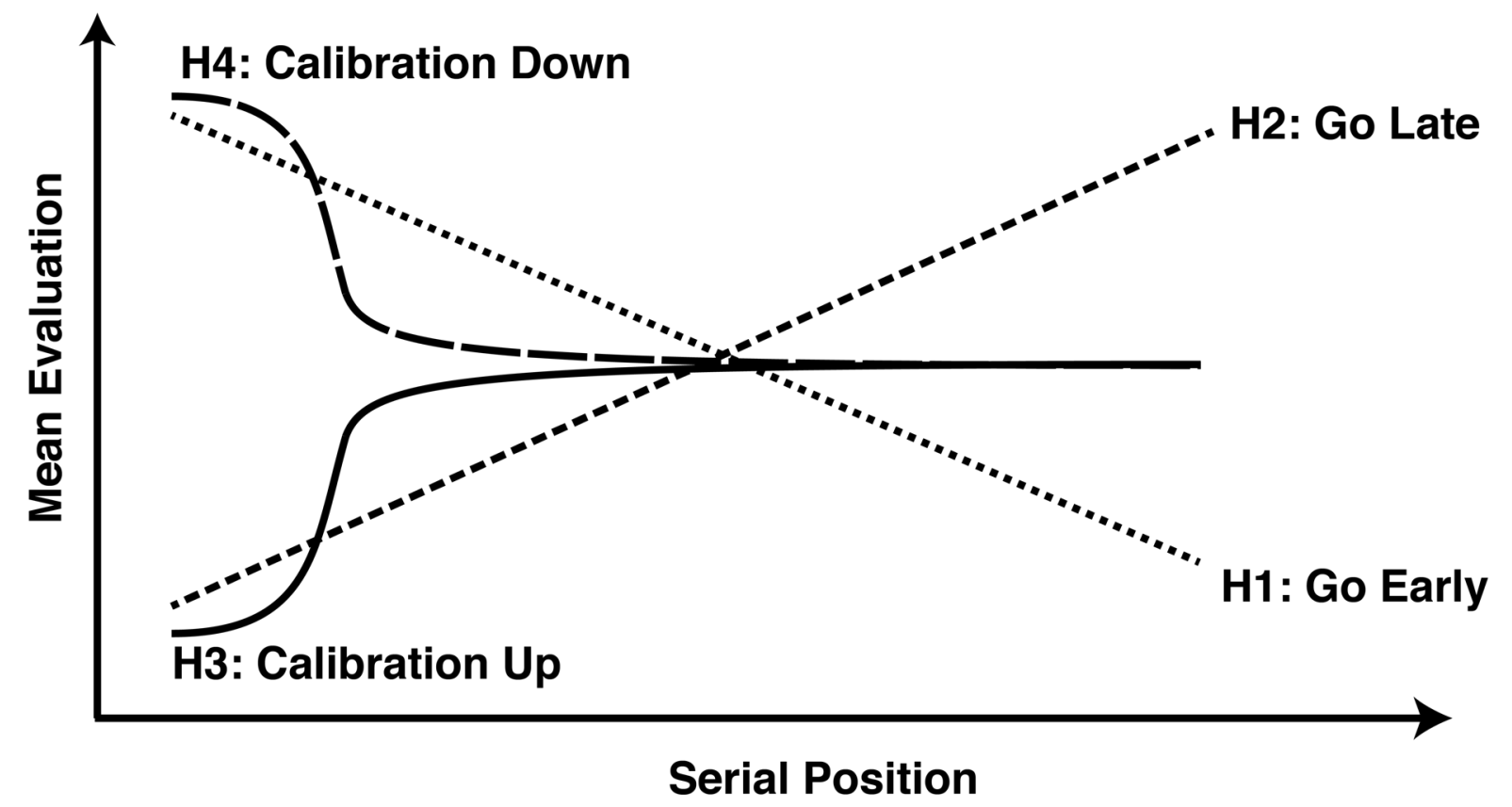

Notes: The diagram illustrates how the mean evaluation of a stimulus changes with serial position under different theories of the effect of serial position. The "go late" and "go early" lines show mean evaluations trending up or down with position. The two "calibration" lines shows that evaluations are initially low or high until calibration is complete, after which they are without trend.

alternatives presented (Berger, 2016). As a result, they trend away from taking action as they see more alternatives. Fourth, initial presentations tend to create a standard for decision criteria, leading judges to look for later performances to exceed those of earlier ones, creating a ratcheting up of standards (Wagner and Klein, 2007; Farr and York, 1975; Feenberg et al, 2015; Danziger, Levav, \& Avnaim-Pesso, 2011). Fifth, evaluators "satisfice" and choose the first acceptable alternative (Feenberg et al, 2015; Karlsson, Massa, \& Simonov, 2006; Haque \& Ginsparg, 2009; Huang, 2014). These arguments lead to the first hypothesis:

H1: Investors' interest in further investigating new ventures pitched to them will decrease as one moves later in the pitch order. 


\section{The "go late" argument}

The second hypothesis that emerges from research on the effect of order in competitive settings suggests the opposite of the first hypothesis: investor interest in further investigation of founder pitches should be an increasing function position in the order. The general principle behind this effect is that ideas presented later tend to receive more positive evaluations than those presented earlier (Almilia et al, 2013; Diagle et al, 2015; Kerstolt and Jackson, 1998). First, when there is a mix of positive and negative information, the most recent information tends to get more weight (Daigle et al 2015; Feenberg et al, 2015). Second, over time people tend to become fatigued by repeated decisions and become less critical (Feenberg et al 2015). Third, judges implicitly compare performances to each other. Because negative attributes are more likely to be remembered than positive features (Baumeister et al, 2001), each new performance seems better than the one before it (Bruine de Bruin \& Keren, 2003; Houston, Sherman, \& Baker, 1989). Fourth, participants' motivation is enhanced by watching others participate first (Bruine de Bruine \& Keren, 2003). This argument leads to the second hypothesis:

H2: Investors' interest in further investigating new ventures pitched to them will increase as one moves later in the pitch order.

\section{The "calibration up" argument}

The third hypothesis that emerges from research on the effect of order in competitive settings is that investor interest in further investigation of founder pitches is initially low and then increases as evaluators calibrate to the quality of the average performance in the competition. Initially, participants receive low scores because judges enter competitive settings with a high 
expectation for average performance. For example, in figure skating competitions might expect Olympic-quality performances even when judging young skaters. Similarly, investors might expect to see companies that resemble those of Airbnb or Uber when hearing pitches at an accelerator's demo day. After a few performances or presentations, evaluators come to realize that the average quality is lower than they had originally expected. As a result, they change their assessments. They adjust for lower overall quality than they had initially expected, so that they may reach a target share of positive evaluations. (Clingingsmith \& Shane, 2016; Hsu, 2004). This argument leads to the third hypothesis:

H3: Investors' interest in further investigating new ventures pitched to them will be low for the first few pitches in the order and then will not vary across subsequent positions.

\section{The "calibration down" argument}

The fourth hypothesis suggested by the effect of order in competitive settings is the opposite of the third hypothesis: Investor interest in further investigation of founder pitches is initially high and then decreases, as evaluators calibrate to the quality of the average performance in the competition. Initially, participants receive high scores because judges enter competitive settings with low expectations for average performance. For, example evaluators think that the participants are "only students" or are founders "at the very early stage of venture development" so their ex ante expectations for quality are low relative to actual performance. After a few performances or presentations, evaluators come to realize that the average quality is higher than they had originally expected. As a result, they change their assessments. They decrease their 
evaluations to reach a target share of positive evaluations. This argument leads to the fourth hypothesis:

H4: Investors' interest in further investigating new ventures pitched to them will be high for the first few pitches in the order and then will not vary across subsequent positions.

\section{Experimental Design, Measures, and Methods}

We ran four pitch competitions at Northeast Ohio universities in the fall of 2015. Participants had 90 seconds to present their own original business idea to a panel of judges drawn from the local investment community. The competitions ran from 9 a.m. to 4 p.m. on a Saturday. Each of the competitions had identical prize money: first place was $\$ 2,500$, second place was $\$ 1,000$, and third place was $\$ 500$. Participants signed up in advance using an online tool. The participants varied both demographically and in pitch experience.

When participants arrived at competition, they checked in and were directed into a holding room where they completed a demographic survey. Once check-in was complete, each participant was randomly assigned a judge panel, a place in the pitch order, and one of four training treatments or a null treatment. Each treatment group had a facilitator that stayed with the group throughout the day. The facilitator assembled the participants in his or her group and led them to a separate training room. The participants received training and developed their pitches. After completing the final drafts of their pitches, the participants were provided with lunch.

In the afternoon, participants delivered their 90 second elevator pitch to the panel of three to four judges to which they had been randomly assigned. Each panel was seated in a separate room. Participants were called from their training rooms in their randomly assigned order to pitch 
to the panel. The pitches were limited to 90 seconds using a timer. The panel asked one question of each presenter, which the presenter then answered. Upon completion of the pitch and question and answer period, the judges scored the pitch immediately. The participant was then asked to leave the area of the experiment and return later to learn the results of the competition. Presentations continued without breaks until all participants assigned to a given panel had delivered their pitches.

Judges were recruited from the Northeast Ohio entrepreneurship ecosystem. All judges were accredited investors, ${ }^{3}$ but they varied in their early stage venture finance activity.

Descriptive statistics for participants and judges are shown in Table 1. The average age of participants was 23. Most were male (68\%) undergraduates (74\%). More than half had taken courses in business or entrepreneurship. A third had given a pitch before. The average judge was in his late forties. Only 14\% of judges were female. More than half were active venture capitalists, business angels, or mentors. All were accredited investors.

To promote ecological validity, we had the judges use their interest in further consideration of the business ideas for investment as the criteria for evaluation. The judges scored the pitches using 7-point Likert-scale questions from "strongly disagree" to "strongly agree." There were four

3 Most of the investors were accredited investors by virtue of this individual definition. A few were accredited investors by virtue of the venture capital firm, family office, or angel fund they represented. 
Table 1. Descriptive Statistics

\begin{tabular}{llllll} 
A. Participants, N=271 & Mean & SD & $\begin{array}{l}\text { Mean } \mid \\
\text { Order } \leq 2 \\
(\mathrm{~N}=30)\end{array}$ & $\begin{array}{l}\text { Mean } \mid \\
\text { Order }>2 \\
(\mathrm{~N}=241)\end{array}$ & $\begin{array}{l}\text { Equality } \\
\text { of Means, } \\
\text { P-value }\end{array}$ \\
\hline Age & 22.7 & 5.8 & 21.2 & 22.8 & 0.02 \\
Female & 0.32 & & 0.40 & 0.32 & 0.38 \\
White & 0.56 & & 0.53 & 0.56 & 0.75 \\
Asian & 0.25 & & 0.10 & 0.27 & 0.01 \\
Pitched Before & 0.29 & & 0.20 & 0.30 & 0.20 \\
Has Existing Business & 0.17 & & 0.17 & 0.17 & 0.96 \\
Graduate Student & 0.26 & & 0.10 & 0.28 & 0.01 \\
Studies STEM Field & 0.36 & & 0.23 & 0.37 & 0.11 \\
Taken Entrepreneurship Class & 0.49 & & 0.43 & 0.50 & 0.48 \\
Taken Business Class & 0.63 & & 0.83 & 0.60 & $<0.01$ \\
Above Median Quality Idea & 0.56 & & 0.47 & 0.58 & 0.27 \\
& & & & & \\
B. Judges, N=50 & Mean & SD & & & \\
\hline Years Since College & 26.8 & 12.0 & & & \\
Female & 0.14 & & & & \\
MBA & 0.40 & & & & \\
Lawyer & 0.18 & & & & \\
VC/Angel Investor/Mentor & 0.54 & & & & \\
Active Entrepreneur & 0.16 & &
\end{tabular}

questions: (1) "I would pursue a follow-up meeting to learn more about the venture," (2) "I would be interested in seeing the business plan for this venture," (3) "I would recommend this opportunity to a co-investor," and (4) "I would initiate due diligence on this venture." Responses were aggregated into a score, which we call judge interest, that ranges from 4 to 28 . Cronbach's alpha of this measure was 0.94 . (see Table 2.)

The judges were also asked to rate the content and style of the pitches with two 7 point Likert-scale questions from "very poor" to "excellent." The two items were: (1) "The content of this elevator pitch was..." and (2) "The presentation style of this elevator pitch was ..." The Cronbach's alpha of the measure formed from these items, which we call pitch quality, is 0.86 . 


\section{Table 2. Interest and Pitch Quality Scale}

\begin{tabular}{lccccc}
\multicolumn{1}{c}{ Item } & Sign & $\begin{array}{c}\text { Item-Test } \\
\text { Correlation }\end{array}$ & $\begin{array}{c}\text { Item-Rest } \\
\text { Correlation }\end{array}$ & $\begin{array}{c}\text { Average } \\
\text { Interitem } \\
\text { Covariance }\end{array}$ & Cronbach's $\alpha$ \\
\hline Pursue follow-up meeting & + & 0.92 & 0.85 & 1.81 & 0.92 \\
Read business plan & + & 0.94 & 0.88 & 1.76 & 0.91 \\
Recommend to co-investor & + & 0.90 & 0.82 & 1.96 & 0.92 \\
Initiate Due Diligence & + & 0.91 & 0.84 & 1.90 & 0.92 \\
Judge Interest Scale & & & & 1.86 & 0.94 \\
\hline
\end{tabular}

Pitch content

Pitch style

Pitch Quality Scale

1.49

0.86

We developed an independent measure of the overall quality of the business ideas participants chose to pitch. Three undergraduate students who had taken and received a grade of "A" in an upper-level entrepreneurial finance class rated the first drafts of participant pitches. The class had educated students on the dimensions of start-up companies that are appealing to investors in part through interaction with prominent angel investors and venture capitalists. ${ }^{4}$ The three students each read each of the first-draft pitches and coded them for the quality of the business described using a 10-point Likert scale. In conducting their evaluation, the students were asked to apply the concepts that they had learned from prominent practitioners about what makes an attractive start-up venture and then form their own subjective evaluation. The quality measure used in our analysis is the sum of the three evaluators' quality scores. The intraclass correlation of the average evaluations of quality of the three coders was 0.73 .

\footnotetext{
${ }^{4}$ Angel investors interacting with the class were members of the Angel Capital Association Board. Venture capitalists were partners at firms such as Greylock and Sequoia Capital.
} 
We measure the effect of pitch order on judges' interest using a regression at the judgeparticipant level. Let $s_{i j}$ be a variable measuring the interest of judge $j$ to the pitch delivered by participant $i$. The length of pitch panels varied between 15 and 22 as the number of individuals who signed up for each competition varied. Divide the 22 possible serial positions into a set of $C$ sequential position categories where $C \leq 22$. The dummy variable $I_{i j n}$ indicates that participant $\mathrm{i}$ pitched in position category $n$. In the following specification, the coefficients $\beta_{n}$ measures the effect of being in position category $n$ on interest relative to being in the first position category, which is captured by $\alpha$.

$$
s_{i j}=\alpha+\sum_{n=2}^{C} \beta_{n} I_{i j n}+X_{i}^{\prime} \theta+\varepsilon_{i j}
$$

The vector $X_{i}$ may contains participant-level control variables and indicator variables for the judges. The term $\varepsilon_{i j}$ represents unexplained variation in interest. When we compute the variancecovariance matrix for this regression, we allow for arbitrary correlation of the $\varepsilon_{i j}$ at the participant level as variation in our variables of interest occurs at that level (Moulton, 1990).

We developed two measures of the experience of our investor-judge. First, we collected the volume of early-stage deals they have been involved in from Crunchbase and split them at the median. Second, we use their LinkedIn profiles to classify them into those who list venture capital, angel investing, or mentoring as their primary activity.

\section{Results}

Our main regression estimates of the effect of randomly assigned position in the pitch order on judge interest are shown in Table 3 . These estimates group all pitches at position 16 or greater in the order but otherwise have a dummy variable for each position. We show order effects without 
Table 3: Effects of Order on Judge Interest

\begin{tabular}{|c|c|c|c|c|c|c|c|c|}
\hline & $\begin{array}{l}\text { Interest } \\
\text { (1) }\end{array}$ & $\begin{array}{c}\text { Interest } \\
(2)\end{array}$ & $\begin{array}{c}\text { Interest } \\
\text { (3) }\end{array}$ & $\begin{array}{l}\text { Interest } \\
\text { (4) }\end{array}$ & $\begin{array}{c}\text { Pursue } \\
\text { Meeting } \\
\text { (5) }\end{array}$ & $\begin{array}{c}\text { Read } \\
\text { Plan } \\
(6)\end{array}$ & $\begin{array}{l}\text { Rec. to } \\
\text { Other } \\
(7)\end{array}$ & $\begin{array}{c}\text { Due } \\
\text { Diligence } \\
(8)\end{array}$ \\
\hline Second & $\begin{array}{c}0.22 \\
(1.12)\end{array}$ & $\begin{array}{c}0.22 \\
(0.98)\end{array}$ & $\begin{array}{l}-0.18 \\
(0.93)\end{array}$ & $\begin{array}{l}-0.41 \\
(1.11)\end{array}$ & $\begin{array}{l}-0.07 \\
(0.28)\end{array}$ & $\begin{array}{l}-0.26 \\
(0.30)\end{array}$ & $\begin{array}{r}0.15 \\
(0.22)\end{array}$ & $\begin{array}{l}-0.00 \\
(0.22)\end{array}$ \\
\hline Third & $\begin{array}{l}2.25^{*} \\
(1.26)\end{array}$ & $\begin{array}{c}1.95 \\
(1.25)\end{array}$ & $\begin{array}{r}1.50 \\
(1.30)\end{array}$ & $\begin{array}{r}0.50 \\
(1.44)\end{array}$ & $\begin{array}{r}0.34 \\
(0.37)\end{array}$ & $\begin{array}{r}0.24 \\
(0.42)\end{array}$ & $\begin{array}{l}0.47 * \\
(0.28)\end{array}$ & $\begin{array}{c}0.45 \\
(0.29)\end{array}$ \\
\hline Fourth & $\begin{array}{r}4.18 * * * \\
(1.31)\end{array}$ & $\begin{array}{r}4.09 * * * \\
(1.28)\end{array}$ & $\begin{array}{r}3.80 * * * \\
(1.05)\end{array}$ & $\begin{array}{r}3.13 * * * \\
(1.04)\end{array}$ & $\begin{array}{r}0.92 * * * \\
(0.30)\end{array}$ & $\begin{array}{r}0.90 * * * \\
(0.32)\end{array}$ & $\begin{array}{r}1.01 * * * \\
(0.25)\end{array}$ & $\begin{array}{r}0.97 * * * \\
(0.25)\end{array}$ \\
\hline Fifth & $\begin{array}{r}3.44 * * * \\
(1.19)\end{array}$ & $\begin{array}{r}3.57 * * * \\
(1.34)\end{array}$ & $\begin{array}{r}2.77 * * \\
(1.29)\end{array}$ & $\begin{array}{r}2.42 * * \\
(1.18)\end{array}$ & $\begin{array}{l}0.72 * \\
(0.38)\end{array}$ & $\begin{array}{r}0.61 \\
(0.39)\end{array}$ & $\begin{array}{r}0.69 * * \\
(0.29)\end{array}$ & $\begin{array}{r}0.75 * * \\
(0.32)\end{array}$ \\
\hline Sixth & $\begin{array}{c}3.05^{*} \\
(1.57)\end{array}$ & $\begin{array}{c}3.43^{* *} \\
(1.42)\end{array}$ & $\begin{array}{r}2.82 * * \\
(1.24)\end{array}$ & $\begin{array}{r}2.78 * * \\
(1.38)\end{array}$ & $\begin{array}{l}0.62 * \\
(0.36)\end{array}$ & $\begin{array}{r}0.55 \\
(0.37)\end{array}$ & $\begin{array}{r}0.79 * * * \\
(0.28)\end{array}$ & $\begin{array}{r}0.85^{* * * *} \\
(0.27)\end{array}$ \\
\hline Seventh & $\begin{array}{r}2.84 * * \\
(1.39)\end{array}$ & $\begin{array}{r}2.57 * * \\
(1.20)\end{array}$ & $\begin{array}{l}1.81^{*} \\
(1.09)\end{array}$ & $\begin{array}{l}2.27^{*} \\
(1.19)\end{array}$ & $\begin{array}{r}0.42 \\
(0.33)\end{array}$ & $\begin{array}{r}0.35 \\
(0.35)\end{array}$ & $\begin{array}{r}0.57 * * \\
(0.26)\end{array}$ & $\begin{array}{r}0.47 * * \\
(0.24)\end{array}$ \\
\hline Eighth & $\begin{array}{l}2.72 * \\
(1.49)\end{array}$ & $\begin{array}{r}2.83 * * \\
(1.43)\end{array}$ & $\begin{array}{r}2.16 \\
(1.40)\end{array}$ & $\begin{array}{r}2.22 \\
(1.48)\end{array}$ & $\begin{array}{r}0.60 \\
(0.42)\end{array}$ & $\begin{array}{r}0.38 \\
(0.43)\end{array}$ & $\begin{array}{l}0.59^{*} \\
(0.30)\end{array}$ & $\begin{array}{l}0.59^{*} \\
(0.32)\end{array}$ \\
\hline Ninth & $\begin{array}{c}2.46^{* *} \\
(1.10)\end{array}$ & $\begin{array}{r}2.46^{* *} \\
(1.18)\end{array}$ & $\begin{array}{r}2.58^{* *} \\
(1.21)\end{array}$ & $\begin{array}{r}2.62 * * \\
(1.27)\end{array}$ & $\begin{array}{r}0.76^{* *} \\
(0.37)\end{array}$ & $\begin{array}{r}0.61 \\
(0.37)\end{array}$ & $\begin{array}{r}0.65^{* *} \\
(0.28)\end{array}$ & $\begin{array}{c}0.55^{*} \\
(0.28)\end{array}$ \\
\hline Tenth & $\begin{array}{c}3.42 * * * \\
\quad(1.28)\end{array}$ & $\begin{array}{r}3.64 * * * \\
(1.23)\end{array}$ & $\begin{array}{r}3.56^{* * * *} \\
(1.13)\end{array}$ & $\begin{array}{r}3.19 * * \\
(1.26)\end{array}$ & $\begin{array}{r}0.87 * * * \\
(0.34)\end{array}$ & $\begin{array}{r}0.74 * * \\
(0.35)\end{array}$ & $\begin{array}{r}1.01 * * * \\
(0.26)\end{array}$ & $\begin{array}{r}0.93 * * * \\
(0.26)\end{array}$ \\
\hline Eleventh & $\begin{array}{r}2.95 * * \\
(1.28)\end{array}$ & $\begin{array}{r}3.02 * * * \\
(1.07)\end{array}$ & $\begin{array}{r}2.28 * * \\
(1.02)\end{array}$ & $\begin{array}{l}1.93^{*} \\
(1.11)\end{array}$ & $\begin{array}{r}0.53 \\
(0.33)\end{array}$ & $\begin{array}{r}0.40 \\
(0.30)\end{array}$ & $\begin{array}{r}0.75^{* * *} \\
(0.23)\end{array}$ & $\begin{array}{r}0.61 * * \\
(0.24)\end{array}$ \\
\hline Twelfth & $\begin{array}{r}3.61 * * \\
(1.76)\end{array}$ & $\begin{array}{r}3.52 * * \\
(1.54)\end{array}$ & $\begin{array}{l}2.46^{*} \\
(1.42)\end{array}$ & $\begin{array}{r}1.78 \\
(1.41)\end{array}$ & $\begin{array}{r}0.56 \\
(0.42)\end{array}$ & $\begin{array}{r}0.37 \\
(0.41)\end{array}$ & $\begin{array}{r}0.80 * * \\
(0.33)\end{array}$ & $\begin{array}{r}0.72 * * \\
(0.32)\end{array}$ \\
\hline Thirteenth & $\begin{array}{r}3.23 * * \\
(1.36)\end{array}$ & $\begin{array}{r}3.36^{* * *} \\
(1.17)\end{array}$ & $\begin{array}{r}2.86^{* *} \\
(1.11)\end{array}$ & $\begin{array}{r}2.55^{* *} \\
(1.22)\end{array}$ & $\begin{array}{l}0.63 * \\
(0.34)\end{array}$ & $\begin{array}{r}0.50 \\
(0.33)\end{array}$ & $\begin{array}{r}0.87 * * * \\
(0.23)\end{array}$ & $\begin{array}{r}0.86^{* * * *} \\
(0.28)\end{array}$ \\
\hline Fourteenth & $\begin{array}{c}1.44 \\
(1.27)\end{array}$ & $\begin{array}{c}1.44 \\
(1.26)\end{array}$ & $\begin{array}{r}0.85 \\
(1.14)\end{array}$ & $\begin{array}{r}0.93 \\
(1.13)\end{array}$ & $\begin{array}{r}0.12 \\
(0.35)\end{array}$ & $\begin{array}{r}0.02 \\
(0.34)\end{array}$ & $\begin{array}{r}0.37 \\
(0.26)\end{array}$ & $\begin{array}{c}0.35 \\
(0.26)\end{array}$ \\
\hline Fifteenth & $\begin{array}{c}2.16^{* *} * \\
(0.99)\end{array}$ & $\begin{array}{c}2.16^{* *} \\
(1.03)\end{array}$ & $\begin{array}{r}1.43 \\
(1.05)\end{array}$ & $\begin{array}{r}1.63 \\
(1.10)\end{array}$ & $\begin{array}{r}0.29 \\
(0.32)\end{array}$ & $\begin{array}{r}0.24 \\
(0.32)\end{array}$ & $\begin{array}{l}0.46^{*} \\
(0.24)\end{array}$ & $\begin{array}{l}0.44 * \\
(0.24)\end{array}$ \\
\hline Sixteenth + & $\begin{array}{r}3.30 * * * \\
(0.98)\end{array}$ & $\begin{array}{r}3.58 * * * \\
(0.92)\end{array}$ & $\begin{array}{r}2.92 * * * \\
(0.86)\end{array}$ & $\begin{array}{r}2.93 * * * \\
(0.91)\end{array}$ & $\begin{array}{r}0.67 * * * \\
(0.26)\end{array}$ & $\begin{array}{l}0.54 * \\
(0.28)\end{array}$ & $\begin{array}{r}0.83 * * * \\
(0.20)\end{array}$ & $\begin{array}{r}0.88 * * * \\
(0.19)\end{array}$ \\
\hline Constant & $\begin{array}{r}11.88 * * * \\
(0.71)\end{array}$ & & & & & & & \\
\hline Adjusted $\mathrm{R}^{2}$ & 0.02 & 0.24 & 0.31 & 0.34 & 0.25 & 0.25 & 0.42 & 0.40 \\
\hline$N$ & 897 & 897 & 897 & 897 & 897 & 897 & 897 & 897 \\
\hline Controls & $\mathrm{N}$ & $\mathrm{N}$ & $\mathrm{Y}$ & $\mathrm{N}$ & $\mathrm{Y}$ & $\mathrm{Y}$ & $\mathrm{Y}$ & $\mathrm{Y}$ \\
\hline Sat. Controls & $\mathrm{N}$ & $\mathrm{N}$ & $\mathrm{N}$ & $\mathrm{Y}$ & $\mathrm{N}$ & $\mathrm{N}$ & $\mathrm{N}$ & $\mathrm{N}$ \\
\hline Judge Effects & $\mathrm{N}$ & $\mathrm{Y}$ & $\mathrm{Y}$ & $\mathrm{Y}$ & $\mathrm{Y}$ & $\mathrm{Y}$ & $\mathrm{Y}$ & $\mathrm{Y}$ \\
\hline DV Mean & 14.54 & 14.54 & 14.54 & & 14.54 & 14.54 & 14.54 & 14.54 \\
\hline
\end{tabular}

Notes: Standard errors are corrected for clustering at the participant level. Controls include age, gender, white or Asian identity, whether pitched before, experience operating a business, graduate student, STEM field, and whether taken an entrepreneurship course or other business course. Saturated controls include interactions between the Asian, grad student, and business experience dummies with six age-category dummies. Judge dummies indicate identity of randomly assigned judge. Stars indicate statistical significance of tests of the null hypothesis that the coefficient is zero: * mean $\mathrm{p}<0.10 ; * *$ means $\mathrm{p}<0.05$; and $* * *$ means $\mathrm{p}<0.01$. 
controls or judge indicators in column 1 . The mean interest for pitch slot one is 11.9 , as shown by the constant term. There is no significant difference in interest at slot two, but slot three is 2.25 points higher $(\mathrm{p}=0.08)$ and slot four is 4.18 points higher $(\mathrm{p}<0.01)$. The remaining slots are about 2.5 points higher on average than slot one. The pattern is unchanged when we introduce judge effects in column 2, although the precision of the estimates increases somewhat. Note that the increase in explained variance between columns 1 and 2 when fixed effects are included shows that there are sizable idiosyncratic components to the way judges score. Introducing controls for participant characteristics in column 3 again leaves the pattern unchanged.

Figure 2 uses the estimates from Table 3, column 3 to illustrate the order effects pattern visually. The figure makes it clear that entrepreneurs who pitch investors in the first two slots in

Figure 2. Effects of Pitch Order on Judge Interest.

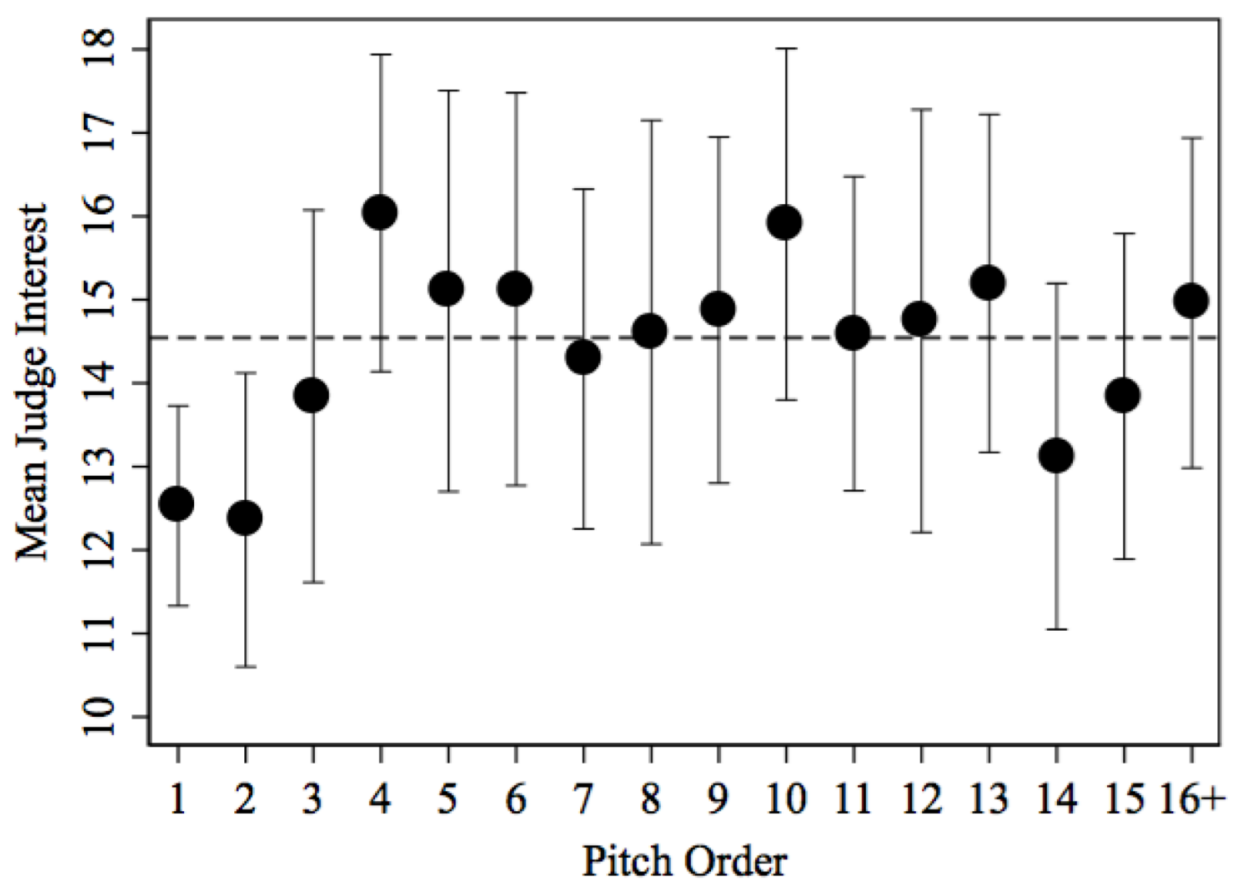

Notes: $\mathrm{N}=897$. Dots show mean judge interest for each randomly assigned place in the pitch order. The dashed line shows the overall mean (14.54). Panels judged between 15 and 22 pitches. Pitch order of 16 or greater are pooled. Mean interest computed using equation 1 and includes controls for participant characteristics and judge effects. The 95 percent confidence intervals allow for clustering at the participant level. 
each panel perform worse than others. Pitching first or second reduces the average interest by about two points $(\mathrm{p}<0.01)$ versus the mean place in the order, or about 0.36 standard deviations. The magnitude of the order effect can be gauged by noting that pitching in the first or second slot rather than at an average slot would shift the best pitch from each competition from first place to fourth place. Because the first three participants in the competition received prize money, this effect is large enough to influence who received money and who did not.

While random assignment guarantees that pitch order will be uncorrelated with participant characteristics in expectation, we check to see whether there were realized differences between those who pitched earlier and those who pitched later in Table 1 . Early pitchers were statistically significantly more likely to be younger, non-Asian, undergraduate, and to have taken business classes. Accordingly, Table 3, column 4 includes as controls full interactions of Asian, grad student, and business experience with a set of six age dummies. The robustness of the results to these saturated controls show that these differences are not driving the results.

Recall that our judge interest variable is the sum of four components. Columns 4 through 7 of Table 3 show that the pattern of lower interest for slots one and two carries is robust to looking at the components individually.

Next, we explore whether the pattern of low scores in the first and second slot varies by the characteristics of the participants and their ideas using interactions with pitch order. To overcome sample size limitations, we collapse the order variable into three categories: first or second, third or fourth, and fifth or higher. We make first and second the omitted category. Table 4 shows that the order effects pattern is relatively homogenous across individuals with different characteristics. The only statistically significant interactions suggest that order effects may be stronger for those who have taken an entrepreneurship class. 
Table 4: Tests for Differential Effects of Order on Judge Interest By Participant Characteristics

\begin{tabular}{lcccccc}
\hline Interacted & & & & & Pitched & Existing \\
Characteristic & None & Trained & Age $\leq 21$ & Female & Before & 3usiness \\
& $(1)$ & $(2)$ & $(3)$ & $(4)$ & $(5)$ & $(6)$ \\
\hline Third or Fourth & $2.97 * * *$ & $3.47^{* * *}$ & $4.04 * * *$ & $3.07 * * *$ & $3.04 * * *$ & $2.78^{* * *}$ \\
& $(0.81)$ & $(0.93)$ & $(1.17)$ & $(0.95)$ & $(1.01)$ & $(0.85)$ \\
Fifth and Higher & $2.59^{* * *}$ & $3.13^{* * *}$ & $3.50^{* * *}$ & $2.47 * * *$ & $2.58^{* * *}$ & $2.56^{* * *}$ \\
& $(0.53)$ & $(0.71)$ & $(0.78)$ & $(0.63)$ & $(0.63)$ & $(0.58)$ \\
Third or Fourth X Characteristic & & -0.67 & -1.76 & -0.26 & -0.22 & 2.17 \\
& & $(1.21)$ & $(1.69)$ & $(1.76)$ & $(1.58)$ & $(1.73)$ \\
Fifth and Higher X Characteristic & & -0.67 & -1.56 & 0.32 & 0.03 & 0.14 \\
& & $(0.56)$ & $(1.06)$ & $(1.15)$ & $(0.92)$ & $(1.40)$ \\
\hline Adjusted R ${ }^{2}$ & 0.34 & 0.34 & 0.34 & 0.34 & 0.34 & 0.34 \\
$N$ & 897 & 897 & 897 & 897 & 897 & 897 \\
\hline
\end{tabular}

\begin{tabular}{|c|c|c|c|c|c|c|}
\hline $\begin{array}{l}\text { Interacted } \\
\text { Characteristic }\end{array}$ & $\begin{array}{l}\text { Asian } \\
(7)\end{array}$ & $\begin{array}{l}\text { White } \\
(8)\end{array}$ & $\begin{array}{c}\text { Grad } \\
\text { Student } \\
(9)\end{array}$ & $\begin{array}{c}\text { STEM } \\
\text { Field } \\
(10) \\
\end{array}$ & $\begin{array}{l}\text { Entp. } \\
\text { Course } \\
(11)\end{array}$ & $\begin{array}{c}\text { Business } \\
\text { Course } \\
\text { (12) }\end{array}$ \\
\hline Third or Fourth & $\begin{array}{r}2.94 * * * \\
(1.01)\end{array}$ & $\begin{array}{r}2.52^{* * * *} \\
(0.92)\end{array}$ & $\begin{array}{c}3.03 * * * \\
(0.97)\end{array}$ & $\begin{array}{r}3.13^{* * * *} \\
(0.91)\end{array}$ & $\begin{array}{r}1.26 \\
(0.92)\end{array}$ & $\begin{array}{r}3.29^{* *} \\
(1.55)\end{array}$ \\
\hline Fifth and Higher & $\begin{array}{r}2.50 * * * \\
(0.57)\end{array}$ & $\begin{array}{r}2.23 * * * \\
(0.78)\end{array}$ & $\begin{array}{l}2.43 * * * \\
(0.58)\end{array}$ & $\begin{array}{r}3.06 * * * \\
(0.58)\end{array}$ & $\begin{array}{r}1.72 * * * \\
(0.66)\end{array}$ & $\begin{array}{r}2.95^{* *} \\
(1.29)\end{array}$ \\
\hline Third or Fourth X Characteristic & $\begin{array}{r}0.62 \\
(1.85)\end{array}$ & $\begin{array}{r}0.81 \\
(1.52)\end{array}$ & $\begin{array}{c}0.42 \\
(1.90)\end{array}$ & $\begin{array}{l}-0.75 \\
(2.09)\end{array}$ & $\begin{array}{r}4.37 * * \\
(1.71)\end{array}$ & $\begin{array}{l}-0.37 \\
(1.91)\end{array}$ \\
\hline Fifth and Higher X Characteristic & $\begin{array}{r}0.83 \\
(1.54) \\
\end{array}$ & $\begin{array}{r}0.64 \\
(1.12) \\
\end{array}$ & $\begin{array}{c}1.38 \\
(1.37) \\
\end{array}$ & $\begin{array}{l}-1.93 \\
(1.23) \\
\end{array}$ & $\begin{array}{r}2.11 * * \\
(0.98) \\
\end{array}$ & $\begin{array}{l}-0.44 \\
(1.42) \\
\end{array}$ \\
\hline Adjusted $\mathrm{R}^{2}$ & 0.34 & 0.34 & 0.34 & 0.34 & 0.34 & 0.34 \\
\hline$N$ & 897 & 897 & 897 & 897 & 897 & 897 \\
\hline \multicolumn{7}{|c|}{$\begin{array}{l}\text { Notes: All regressions include controls for participant characteristics and judge dummies. Standard errors are } \\
\text { corrected for clustering at the participant level. Controls include age, gender, white or Asian identity, whether } \\
\text { pitched before, experience operating a business, graduate student, STEM field, and whether taken an } \\
\text { entrepreneurship course or other business course. Judge dummies indicate identity of randomly assigned } \\
\text { judge. Order dummies indicate randomly assigned pitch order. Stars indicate statistical significance of tests of } \\
\text { the null hypothesis that the coefficient is zero: * mean } p<0.10 \text {; } * * \text { means } p<0.05 \text {; and } * * * \text { means } p<0.01 \text {. }\end{array}$} \\
\hline
\end{tabular}

This analysis addresses two important concerns. First, it is plausible that because the participants in our study are students, judges react differently to them than they would to entrepreneurs in a different setting. However, we see that order effects are the same for those participants who already have an existing business and who have pitched business ideas before 
Table 5. Order Effects on Judge Assessment of Pitch Quality

\begin{tabular}{|c|c|c|c|}
\hline & $\begin{array}{c}\text { Pitch Quality } \\
\text { (1) }\end{array}$ & $\begin{array}{c}\text { Pitch Quality } \\
\text { (2) }\end{array}$ & $\begin{array}{c}\text { Pitch Quality } \\
\text { (3) }\end{array}$ \\
\hline Second & $\begin{array}{c}0.44 \\
(0.78)\end{array}$ & $\begin{array}{c}0.44 \\
(0.81)\end{array}$ & $\begin{array}{c}0.37 \\
(0.78)\end{array}$ \\
\hline Third & $\begin{array}{l}1.48^{*} \\
(0.81)\end{array}$ & $\begin{array}{l}1.41 \\
(0.87)\end{array}$ & $\begin{array}{l}1.15 \\
(0.83)\end{array}$ \\
\hline Fourth & $\begin{array}{l}2.12 * * * \\
(0.71)\end{array}$ & $\begin{array}{l}2.07 * * \\
(0.84)\end{array}$ & $\begin{array}{l}2.05^{* * *} \\
(0.78)\end{array}$ \\
\hline Fifth & $\begin{array}{l}2.05 * * \\
(0.85)\end{array}$ & $\begin{array}{l}2.10^{* *} \\
(0.95)\end{array}$ & $\begin{array}{l}1.74^{*} \\
(0.89)\end{array}$ \\
\hline Sixth & $\begin{array}{l}1.96^{* *} \\
(0.95)\end{array}$ & $\begin{array}{l}2.04^{* *} \\
(0.93)\end{array}$ & $\begin{array}{l}1.90^{* *} \\
(0.80)\end{array}$ \\
\hline Seventh & $\begin{array}{l}1.60 * * \\
(0.79)\end{array}$ & $\begin{array}{l}1.52^{*} \\
(0.84)\end{array}$ & $\begin{array}{c}1.27 \\
(0.78)\end{array}$ \\
\hline Eighth & $\begin{array}{l}1.88^{* *} \\
(0.83)\end{array}$ & $\begin{array}{l}1.93 * * \\
(0.86)\end{array}$ & $\begin{array}{l}1.81^{* *} \\
(0.85)\end{array}$ \\
\hline Ninth & $\begin{array}{l}2.62 * * * \\
(0.73)\end{array}$ & $\begin{array}{l}2.62 * * * \\
(0.84)\end{array}$ & $\begin{array}{l}2.84 * * * \\
(0.80)\end{array}$ \\
\hline Tenth & $\begin{array}{l}1.64 * \\
(0.85)\end{array}$ & $\begin{array}{l}1.63^{*} \\
(0.95)\end{array}$ & $\begin{array}{l}1.63^{*} \\
(0.93)\end{array}$ \\
\hline Eleventh & $\begin{array}{l}2.07 * * * \\
(0.71)\end{array}$ & $\begin{array}{l}2.09 * * * \\
(0.77)\end{array}$ & $\begin{array}{l}1.92 * * * \\
(0.73)\end{array}$ \\
\hline Twelfth & $\begin{array}{l}1.73 * * \\
(0.82)\end{array}$ & $\begin{array}{l}1.68^{*} \\
(0.86)\end{array}$ & $\begin{array}{c}1.30 \\
(0.87)\end{array}$ \\
\hline Thirteenth & $\begin{array}{l}2.27 * * * \\
(0.73)\end{array}$ & $\begin{array}{l}2.31 * * * \\
(0.78)\end{array}$ & $\begin{array}{l}2.12 * * * \\
(0.77)\end{array}$ \\
\hline Fourteenth & $\begin{array}{l}1.90 * * \\
(0.75)\end{array}$ & $\begin{array}{l}1.90 * * \\
(0.88)\end{array}$ & $\begin{array}{l}1.78 * * \\
(0.77)\end{array}$ \\
\hline Fifteenth & $\begin{array}{l}1.98 * * * \\
(0.75)\end{array}$ & $\begin{array}{l}1.98 * * \\
(0.80)\end{array}$ & $\begin{array}{l}1.69 * * \\
(0.79)\end{array}$ \\
\hline Sixteenth + & $\begin{array}{l}2.00 * * * \\
(0.66)\end{array}$ & $\begin{array}{l}2.17 * * * \\
(0.75)\end{array}$ & $\begin{array}{l}1.89 * * * \\
(0.71)\end{array}$ \\
\hline Constant & $\begin{array}{l}7.16^{* * *} \\
(0.57)\end{array}$ & & \\
\hline Adjusted R2 & 0.04 & 0.15 & 0.24 \\
\hline$N$ & 897 & 897 & 897 \\
\hline Controls & $\mathrm{N}$ & $\mathrm{N}$ & $\mathrm{Y}$ \\
\hline Judge Dummies & $\mathrm{N}$ & $\mathrm{Y}$ & $\mathrm{Y}$ \\
\hline DV Mean & 14.54 & 14.54 & 14.54 \\
\hline
\end{tabular}

Notes: Outcome is judges' combined assessment of the quality of content and style of the pitch. Standard errors are corrected for clustering at the participant level. Controls include age, gender, white or Asian identity, whether pitched before, experience operating a business, graduate student, STEM field, and whether taken an entrepreneurship course or other business course. Judge dummies indicate identity of randomly assigned judge. Stars indicate statistical significance of tests of the null hypothesis that the coefficient is zero: * mean $\mathrm{p}<0.10$; ** means $\mathrm{p}<0.05$; and $* * *$ means $\mathrm{p}<0.01$.

(columns 5 and 6). Second, it could be that our pitch training exercise created the order effects.

This is unlikely because the order effects are the same for those who had a training treatment and 
the null treatment (column 2).

In addition to expressing their interest in a pitch, judges were also asked to assess the quality of its content and style. Table 5 shows the effects of pitch order on the sum of these quality variables. The overall pattern is the same seen with the judge interest variables: The first two positions in the order are assessed as having lower quality than the rest.

\subsection{Calibration Difficulties}

We argue that participants initially receive lower scores because judges have difficulty calibrating the quality of the initial pitches because the judges have trouble calibrating their evaluations to the overall quality of the presentations. As suggested by hypothesis 3 , they increase their evaluations with position in a way consistent with an adjustment for lower overall quality than they had initially expected and a desire to reach a target share of positive evaluations.

We might expect score adjustment be more pronounced for judges with less investment experience. Inexperienced investors have higher prior beliefs about the quality of new business ideas because public information on new ventures is skewed toward those that are successful and of high quality (Clingingsmith \& Shane, 2016; Hsu, 2004).

Table 6 shows that the more experienced judges tend to show less interest in pitches than less experienced judges, which is consistent with lower priors. Moreover, the table shows that for both measures, the calibration effect is smaller for more experienced investors than less experienced investors. Upward adjustment and lower priors for more experienced investors is consistent with a calibration mechanism where judges initially rate pitches too low because they expect the average pitch will be better than it is and then adjust when information about the average 
Table 6. Differences in Pitch Order Effects by Judge Experience

\begin{tabular}{lcc}
\hline Judge Experience Measure & $\begin{array}{c}\text { High Deal } \\
\text { Volume } \\
(1)\end{array}$ & $\begin{array}{c}\text { VC/Angel/ } \\
\text { Mentor } \\
(2)\end{array}$ \\
\hline Third or Fourth & $3.05^{* * *}$ & $2.86^{* * *}$ \\
& $(0.89)$ & $(0.82)$ \\
Fifth and Higher & $3.52^{* * *}$ & $3.60^{* * *}$ \\
& $(0.57)$ & $(0.59)$ \\
Third or Fourth X More Experienced Judge & -0.56 & -0.16 \\
& $(1.24)$ & $(1.19)$ \\
Fifth and Higher X More Experienced Judge & $-1.80^{* *}$ & $-1.86^{* *}$ \\
& $(0.86)$ & $(0.90)$ \\
\hline Adjusted R ${ }^{2}$ & 0.31 & 0.31 \\
$N$ & 897 & 897 \\
DV Mean & 14.54 & 14.54 \\
\hline Third or Fourth Level Effect, More Experienced Judge & $2.48^{* *}$ & $2.70^{* *}$ \\
Fifth and Higher Level Effect, More Experienced Judge & $1.73^{* *}$ & $1.75^{* *}$ \\
\hline Mean Interest, More Experienced Judge & 14.2 & 13.9 \\
Mean Interest, Less Experienced Judge & 14.9 & 15.3 \\
\hline Notes: The first two pitches are the omitted category dummy. Regressions include controls \\
and judge dummies. Standard errors are corrected for clustering at the participant level. \\
Stars indicate statistical significance of tests of the null hypothesis that the coefficient is \\
zero: * mean p<0.10; ** means p<0.05; and *** means p<0.01
\end{tabular}

pitch is revealed. It is inconsistent with a Bayesian updating mechanism, since we would expect high priors to result in downward, not upward, adjustment.

Note that the calibration effect is likely muted by our design. We designed the scoring system to be "pre-calibrated" to the investor's assessment about whether they would or would not want more information about the venture. The fact that they treated the evaluation as something that needed further adjustment meant that they weren't going with "gut feeling" and had a goal for their average evaluation. The average score of 14.54 is right in the middle of the 4 to 28 scale.

If the average quality of our participants was lower than judges had expected, they might initially score more harshly until the discrepancy become apparent. If this were the case, we would expect the upward adjustment to accrue primarily by the higher quality pitches. (Low quality 


\section{Table 7. Standard Deviation of Scores for Places in the Pitch Order}

\begin{tabular}{ccc} 
Pitch Order & SD of Score & $\begin{array}{c}\text { P-value for } \mathrm{H}_{0}: \\
\text { SD Equal to that } \\
\text { for Pitch Order 5-22 }\end{array}$ \\
\hline 1 & 4.38 & $<0.01$ \\
2 & 4.92 & 0.09 \\
3 & 5.50 & 0.71 \\
4 & 5.33 & 0.30 \\
5 to 22 & 5.70 & \\
\hline
\end{tabular}

Notes: The table reports the standard deviation of scores for the 50

judges for the first four places in the order and place five and higher. P-values are reported from Levene's robust equality of variance test between each of the first four positions and the fifth and higher.

pitches in later places in the pitch order would not receive higher scores because they would not be relatively better than the other pitches already delivered, but high quality pitches in the later places in the pitch order would receive higher scores because they would be relatively better than the other pitches already delivered, even if they did not meet the judges' initial expectations.) We check to see whether the order effects pattern holds at different levels of idea quality in Table 8. The table reveals that all but the bottom $30 \%$ of pitches see large order effects. The effects are particularly pronounced for the upper $10 \%$.

Our results are inconsistent with several alternative explanations for the effects of order on performance as suggested by hypotheses 1,2 and 4 . Those who pitch earliest perform worse than other participants, leading us to rule out hypothesis 1, which suggested the advantage of pitching earlier in the order as explanations for order effects in pitching. Because the judges start with low scores and raise them, we rule out hypothesis 4, which suggested a calibration down. Finally, we rule out hypothesis 2 because the scores do not increase after the initial recalibration.

We also find that the judges may have trouble calibrating the evaluation scheme itself. If there are calibration difficulties, then there should be less variance in the first judgments in a series 
than in later evaluations (Bruine de Bruine \& Keren, 2003). Table 7 shows that the standard deviation of judge scores is, in fact, lower in the first and second positions in the order.

\subsection{Robustness}

We hypothesized that calibration is the mechanism through which the initial low scores operate. If the average quality of our participants was lower than judges had expected, they might initially score more harshly until the discrepancy becomes apparent. If this were the case, we would expect the upward adjustment to accrue primarily by the higher quality pitches. (Low quality pitches in later places in the pitch order would not receive higher scores because they would not be relatively better than the other pitches already delivered, but high quality pitches in the later places in the pitch order would receive higher scores because they would be relatively better than the other pitches already delivered, even if they did not meet the judges' initial expectations.) We check to see whether the order effects pattern holds at different levels of idea quality in Table 8 by interacting our independently coded measure of idea quality with pitch order dummies. The table reveals that all but the bottom $30 \%$ of pitches see large order effects. The effects are particularly pronounced for the upper $10 \%$, providing additional support for our hypothesis.

It is possible, though unlikely, that the order effects we have found reflect a chance assignment of worse-quality pitches to the first two positions in the order. We rule out this possibility by looking for order effects on our independently developed measure of pitch quality. Table 9 shows that by chance tenth place in the order received better ideas than the others, which is not the same pattern we see in order effects in judge interest. 
Table 8: Interactions Between Order Effects and Independent Measure of Idea Quality

\begin{tabular}{|c|c|c|c|c|}
\hline Idea Quality Quantile Dummy & $\begin{array}{c}\geq 30 \text { th } \\
\quad(1)\end{array}$ & $\begin{aligned} \geq & 50 \text { th } \\
& (2)\end{aligned}$ & $\begin{array}{c}\geq 70 \text { th } \\
\quad \text { (3) }\end{array}$ & $\begin{aligned} \geq 90 \text { th } \\
\quad(4)\end{aligned}$ \\
\hline Third or Fourth & $\begin{array}{l}1.88 \\
(1.35)\end{array}$ & $\begin{array}{l}3.29 * * * \\
(1.16)\end{array}$ & $\begin{array}{l}1.98^{*} \\
(1.12)\end{array}$ & $\begin{array}{l}2.67 * * * \\
(0.92)\end{array}$ \\
\hline Fifth and Higher & $\begin{array}{l}1.64^{*} \\
(0.98)\end{array}$ & $\begin{array}{l}2.57 * * * \\
(0.73)\end{array}$ & $\begin{array}{l}2.10^{* * *} \\
(0.67)\end{array}$ & $\begin{array}{l}2.13^{* * *} \\
(0.59)\end{array}$ \\
\hline Third or Fourth X Idea Quality Quantile Dummy & $\begin{array}{l}1.92 \\
(1.77)\end{array}$ & $\begin{array}{l}-0.73 \\
(1.75)\end{array}$ & $\begin{array}{l}1.27 \\
(1.72)\end{array}$ & $\begin{array}{l}1.55 \\
(1.97)\end{array}$ \\
\hline Fifth and Higher X Idea Quality Quantile Dummy & $\begin{array}{l}1.46 \\
(1.16)\end{array}$ & $\begin{array}{l}-0.10 \\
(1.08)\end{array}$ & $\begin{array}{l}0.77 \\
(1.08)\end{array}$ & $\begin{array}{l}3.29 * * * \\
(1.19)\end{array}$ \\
\hline Adjusted $\mathrm{R}^{2}$ & 0.33 & 0.33 & 0.34 & 0.35 \\
\hline$N$ & 897 & 897 & 897 & 897 \\
\hline DV Mean & 14.54 & 14.54 & 14.54 & 14.54 \\
\hline Third or Fourth Level Effect, Upper Tail of Quality & $3.80 * * *$ & $2.56^{* *}$ & $3.25 * * *$ & $4.22 * *$ \\
\hline Fifth and Higher Level Effect, Upper Tail of Quality & $3.10 * * *$ & $2.47 * * *$ & $2.87 * * *$ & $5.41 * * *$ \\
\hline \multicolumn{5}{|c|}{$\begin{array}{l}\text { Notes: Outcome is judges' interest in each pitch. Omitted category is first or second pitch in the order. } \\
\text { Idea quality dummies split the third-party idea quality measure at the indicated decile. All regressions } \\
\text { include controls for participant characteristics and judge dummies. Standard errors are corrected for } \\
\text { clustering at the participant level. Controls include age, gender, white or Asian identity, whether } \\
\text { pitched before, experience operating a business, graduate student, STEM field, and whether taken an } \\
\text { entrepreneurship course or other business course. Judge dummies indicate identity of randomly } \\
\text { assigned judge. Order dummies indicate randomly assigned pitch order. Stars indicate statistical } \\
\text { significance of tests of the null hypothesis that the coefficient is zero: } * \text { mean } p<0.10 \text {; } * * \text { means } p<0.05\end{array}$} \\
\hline
\end{tabular}

Some research argues that going last is better because evaluators focus on information that was more recently made available (Feenberg et al, 2015), because judges increase scores as they approach the end of a session (Danziger, Levav \& Avnaim-Pesso, 2011), or because judges tend to "loosen their standards" over time. Controlling for order, we test for the effect of being the last, second to last, or third to last in Table 10. We fail to reject the null of no effect of being in any of the last three positions in the order, a result that holds whether or not we control for order effects, characteristics, or judge effects. We find no evidence for a benefit of going last.

Our results are also inconsistent with the argument that the judges' evaluations are colored by the pitches that they had heard immediately prior (Epley \& Gilovich, 2006). We test for this by computing the mean score the previous pitch received relative to the median score for that position in the order. We compute the relative score in this way because we have shown that the median score rises with pitch order, and we can to avoid confounding prior score and order effects. Table 
Table 9: Order Effects on Independent Measure of Idea Quality

\begin{tabular}{|c|c|c|c|}
\hline & $\begin{array}{c}\text { Idea Quality } \\
\text { (1) }\end{array}$ & $\begin{array}{c}\text { Idea Quality } \\
\text { (2) }\end{array}$ & $\begin{array}{c}\text { Idea Quality } \\
\text { (3) }\end{array}$ \\
\hline Second & $\begin{array}{c}0.24 \\
(0.42)\end{array}$ & $\begin{array}{c}0.24 \\
(0.44)\end{array}$ & $\begin{array}{c}0.14 \\
(0.41)\end{array}$ \\
\hline Third & $\begin{array}{l}-0.49 \\
(0.39)\end{array}$ & $\begin{array}{l}-0.52 \\
(0.43)\end{array}$ & $\begin{array}{l}-0.92 * * \\
(0.42)\end{array}$ \\
\hline Fourth & $\begin{array}{c}0.48 \\
(0.54)\end{array}$ & $\begin{array}{c}0.46 \\
(0.56)\end{array}$ & $\begin{array}{c}0.23 \\
(0.54)\end{array}$ \\
\hline Fifth & $\begin{array}{c}0.43 \\
(0.45)\end{array}$ & $\begin{array}{c}0.47 \\
(0.45)\end{array}$ & $\begin{array}{c}0.13 \\
(0.38)\end{array}$ \\
\hline Sixth & $\begin{array}{c}0.58 \\
(0.49)\end{array}$ & $\begin{array}{c}0.63 \\
(0.49)\end{array}$ & $\begin{array}{c}0.46 \\
(0.42)\end{array}$ \\
\hline Seventh & $\begin{array}{c}0.48 \\
(0.45)\end{array}$ & $\begin{array}{c}0.46 \\
(0.45)\end{array}$ & $\begin{array}{c}0.10 \\
(0.40)\end{array}$ \\
\hline Eighth & $\begin{array}{r}0.92 * \\
(0.52)\end{array}$ & $\begin{array}{l}0.94^{*} \\
(0.53)\end{array}$ & $\begin{array}{c}0.67 \\
(0.56)\end{array}$ \\
\hline Ninth & $\begin{array}{l}-0.39 \\
(0.38)\end{array}$ & $\begin{array}{l}-0.39 \\
(0.41)\end{array}$ & $\begin{array}{l}-0.58 \\
(0.39)\end{array}$ \\
\hline Tenth & $\begin{array}{l}1.53 * * * \\
(0.46)\end{array}$ & $\begin{array}{l}1.56^{* * *} \\
(0.47)\end{array}$ & $\begin{array}{l}1.47 * * * \\
(0.46)\end{array}$ \\
\hline Eleventh & $\begin{array}{c}0.36 \\
(0.44)\end{array}$ & $\begin{array}{c}0.34 \\
(0.42)\end{array}$ & $\begin{array}{c}0.03 \\
(0.39)\end{array}$ \\
\hline Twelfth & $\begin{array}{c}0.69^{*} \\
(0.41)\end{array}$ & $\begin{array}{c}0.66^{*} \\
(0.40)\end{array}$ & $\begin{array}{l}-0.02 \\
(0.43)\end{array}$ \\
\hline Thirteenth & $\begin{array}{l}-0.21 \\
(0.55)\end{array}$ & $\begin{array}{l}-0.18 \\
(0.53)\end{array}$ & $\begin{array}{l}-0.59 \\
(0.45)\end{array}$ \\
\hline Fourteenth & $\begin{array}{c}0.17 \\
(0.46)\end{array}$ & $\begin{array}{c}0.17 \\
(0.47)\end{array}$ & $\begin{array}{l}-0.12 \\
(0.44)\end{array}$ \\
\hline Fifteenth & $\begin{array}{c}0.10 \\
(0.37)\end{array}$ & $\begin{array}{c}0.10 \\
(0.39)\end{array}$ & $\begin{array}{l}-0.33 \\
(0.35)\end{array}$ \\
\hline Sixteenth + & $\begin{array}{l}0.84 * * \\
(0.36)\end{array}$ & $\begin{array}{l}0.91^{* *} \\
(0.37)\end{array}$ & $\begin{array}{c}0.50 \\
(0.34)\end{array}$ \\
\hline Constant & $\begin{array}{l}3.81 * * * \\
(0.24)\end{array}$ & & \\
\hline Adjusted $\mathrm{R}^{2}$ & 0.08 & 0.09 & 0.23 \\
\hline$N$ & 897 & 897 & 897 \\
\hline Controls & $\mathrm{N}$ & $\mathrm{N}$ & $\mathrm{Y}$ \\
\hline Judge Dummies & $\mathrm{N}$ & $\mathrm{Y}$ & $\mathrm{Y}$ \\
\hline DV Mean & 14.54 & 14.54 & 14.54 \\
\hline
\end{tabular}

Notes: Outcome is mean measure of idea quality as determined by independent raters. Standard errors are corrected for clustering at the participant level. Controls include age, gender, white or Asian identity, whether pitched before, experience operating a business, graduate student, STEM field, and whether taken an entrepreneurship course or other business course. Judge dummies indicate identity of randomly assigned judge. Order dummies indicate randomly assigned pitch order. Stars indicate statistical significance of tests of the null hypothesis that the coefficient is zero: * mean $\mathrm{p}<0.10$; ** means $\mathrm{p}<0.05$; and $* * *$ means $\mathrm{p}<0.01$

11 shows that there is an unconditional relationship between interest in the current pitch and the relative score of the previous pitch (column 1) that survives the addition of controls and order 
Table 10: Effect of Final Positions in the Order on Judge Interest

\begin{tabular}{lcccc}
\hline & $\begin{array}{c}\text { Interest } \\
(1)\end{array}$ & $\begin{array}{c}\text { Interest } \\
(2)\end{array}$ & $\begin{array}{c}\text { Interest } \\
(3)\end{array}$ & $\begin{array}{c}\text { Interest } \\
(4)\end{array}$ \\
\hline Last Pitch & 0.59 & 0.28 & 0.34 & -0.38 \\
& $(1.27)$ & $(1.69)$ & $(1.64)$ & $(1.30)$ \\
Second to Last Pitch & 1.76 & 1.40 & 1.00 & 0.74 \\
& $(1.71)$ & $(1.67)$ & $(1.69)$ & $(1.37)$ \\
Third to Last Pitch & -0.64 & -0.84 & -0.86 & -1.04 \\
& $(1.07)$ & $(1.38)$ & $(1.46)$ & $(1.32)$ \\
Constant & $14.47^{* * *}$ & & & \\
& $(0.28)$ & & & \\
\hline Adjusted R2 & 0.00 & 0.02 & 0.07 & 0.31 \\
$N$ & 897 & 897 & 897 & 897 \\
Controls & $\mathrm{N}$ & $\mathrm{N}$ & $\mathrm{Y}$ & $\mathrm{Y}$ \\
Order Dummies & $\mathrm{N}$ & $\mathrm{Y}$ & $\mathrm{Y}$ & $\mathrm{Y}$ \\
Judge Dummies & $\mathrm{N}$ & $\mathrm{N}$ & $\mathrm{N}$ & $\mathrm{Y}$ \\
DV Mean & 14.54 & 14.54 & 14.54 & 14.54 \\
\hline Note: Oun & & &
\end{tabular}

Notes: Outcome is judges' interest in each pitch. Standard errors are corrected for clustering at the participant level. Controls include age, gender, white or Asian identity, whether pitched before, experience operating a business, graduate student, STEM field, and whether taken an entrepreneurship course or other business course. Judge dummies indicate identity of randomly assigned judge. Order dummies indicate randomly assigned pitch order. Stars indicate statistical significance of tests of the null hypothesis that the coefficient is zero: * mean $\mathrm{p}<0.10$; $* *$ means $\mathrm{p}<0.05$; and $* * *$ means $\mathrm{p}<0.01$.

dummies (column 2). However, in our preferred specification, which includes judge dummies (column 3), which allows each judge to have an idiosyncratic interest level, the effect disappears. We therefore conclude there is no spillover effect in score between the previous pitch and the current pitch.

Our results are inconsistent with the argument that judges serially update their prior beliefs about quality and combine them with information from each pitch to arrive at their interest level. This explanation would suggest continued updating past the first three places in the pitch order, which we do not observe. Moreover, this explanation would suggest that experienced investors, 
Table 11: Effects of Relative Score of Previous Pitch on Judge Interest

\begin{tabular}{lccc}
\hline & Interest & Interest & Interest \\
& $(1)$ & $(2)$ & $(3)$ \\
\hline Relative Score of Previous Pitch & $0.20^{* * *}$ & $0.24 * * *$ & -0.02 \\
& $(0.06)$ & $(0.06)$ & $(0.06)$ \\
Constant & $14.77 * * *$ & & \\
& $(0.27)$ & & \\
\hline Adjusted R2 & 0.02 & 0.09 & 0.30 \\
$N$ & 847 & 847 & 847 \\
Controls & $\mathrm{N}$ & $\mathrm{Y}$ & $\mathrm{Y}$ \\
Order Dummies & $\mathrm{N}$ & $\mathrm{Y}$ & $\mathrm{Y}$ \\
Judge Dummies & $\mathrm{N}$ & $\mathrm{N}$ & $\mathrm{Y}$ \\
DV Mean & 14.54 & 14.54 & 14.54 \\
\hline
\end{tabular}

Notes: Standard errors are corrected for clustering at the participant level. Controls include age, gender, white or Asian identity, whether pitched before, experience operating a business, graduate student, STEM field, and whether taken an entrepreneurship course or other business course. Judge dummies indicate identity of randomly assigned judge. Order dummies indicate randomly assigned pitch order. Stars indicate statistical significance of tests of the null hypothesis that the coefficient is zero: * mean $\mathrm{p}<0.10$; ** means $\mathrm{p}<0.05$; and $* * *$ means $\mathrm{p}<0.01$.

who have better knowledge about how to update and lower priors, would update more than inexperienced investors, which is contrary to what we observe.

Our results are inconsistent with the argument that interest increases with the order because participants' motivation is enhanced by watching others pitch (Bruine de Bruine \& Keren, 2003). Our design rules out this possibility because participants were not permitted to watch the pitches delivered by others.

\section{Discussion}

The rise in start-up accelerators, pitch competitions, and angel groups mean that that it is becoming more common for founders to pitch their new venture ideas to potential investors in a group setting. Although much has been written about the importance of pitches to obtaining 
funding from investors in competitive settings, our study is the first to provide empirical evidence that the order in which pitches occur matters for investors' interest in new businesses.

Prior research on order effects in competitive environments suggested four hypotheses about pitch evaluations would change with order. Our results are consistent with only one of those hypotheses: Pitching in the first or second position is disadvantageous because judges must initially calibrate the evaluation scheme and the quality of the participant pool.

Our findings have important implications for entrepreneurs, competition organizers, and investors. The position to which entrepreneurs are slotted affects who wins prize money. While randomization does not eliminate this effect, it ensures that participants have an equal chance of avoiding the disadvantageous positions (Bruine de Bruine \& Keren, 2003). Therefore, our study suggests the importance of randomly assigning presentation order to the fairness of competitions.

While we do not explicitly study orderings that deliberately put the best ideas first or last, it is reasonable to hypothesize that doing say may disrupt the calibration process. This is another point in favor of a random ordering. In settings where there are more than one group of investors listening to pitches, fairness may be increased by allowing those assigned to pitch first to a given group an opportunity to pitch later in the order to the other group, Investors and entrepreneurs may also benefit from investors being made aware of order effects, as they can avoid missing out on desirable ventures if they can de-bias their assessments.

Our results also show little evidence of evaluator fatigue. Even after hearing more than sixteen presentations, our professional investors showed no fatigue effect. One implication of this pattern is that investors can consider a large number of initial pitches and still maintain their evaluation schema. 
Further, our study indicates the importance of considering the context of competitive settings when assessing order effects. Order effects in start-up pitch competitions are not the same as those in music competitions (Flores \& Ginsburgh, 1996; Ginsburgh \& Van Ours, 2003; Bruine de Bruine \& Keren, 2003), elections (Miller \& Krosnick, 1998), athletics (Wilson, 1977), sales efforts (Wagner \& Klein, 2007), scientific research (Feenberg et al, 2015; Berger, 2016), and judicial proceedings (Kerstholt \& Jackson, 1998; Danziger, Levav, \& Avnaim-Pesso, 2011). Therefore, researchers need to be wary of drawing implications for entrepreneurship from research findings in other settings without testing them in the context of entrepreneurship first. For a field that often borrows explanations from elsewhere this implication could be wide ranging. Just because a theory holds in other aspects of business or the social sciences does not mean that it will hold in new venture creation.

Finally, our study illustrates the power of experimental design for testing causal explanations for aspects of entrepreneurship. Unlike observational studies, experiments allow for random assignment of treatment, permitting researchers to identify causal effects precisely. Our study shows that those experiments can be undertaken not just in the lab but also in the field. This point is important because field experiments allow scholars to avoid the tradeoff of rigor for realism that is a common criticism of laboratory experiments.

Our study is not without limitations. Our sample consists not of experienced entrepreneurs but would-be company founders. Our findings may not generalize to experienced entrepreneurs who are pitching similar types of investors in a group setting. In particular, the calibration effect may depend on how different the average quality of pitches is relative to investor expectations. When these are more closely aligned, there may be less calibration up. It is even possible that a 
group of investors may have expectations below the average quality of presentations, leading to calibration down.

Further, our study is undertaken in Northeast Ohio, a region not known for having large numbers of would-be entrepreneurs or experienced investors. The average level of investor experience and quality of entrepreneurial efforts in our sample may be below that of other regions.

Nevertheless, our findings provide evidence that pitch order matters for investor interest when aspiring entreperenurs pitch their ideas in a group setting. We show that there is a cailbration effect, but that otherwise investors are quite consistent over time in their judgement. These findings have value both in deepening our understanding of the process of raising money and in providing guidance for the design of group pitch settings. 


\section{References}

Almilia, L.S., Hartono, J., Supriyadi, Naharty, E.. (2013). Examining the Effects of Presentation Patterns, Orders, and Information Types in Investment Decision Making. Gadjah Mada International Journal of Business, 15(2), 171-182

Baumeister, R. F., Bratslavsky, E., Finkenauer, C., \& Vohs, K. D. (2001). Bad is stronger than good. Review of General Psychology, 5, 323-370.

Berger, Jonah. 2016. "Does Presentation Order Impact Choice After Delay?” Topics in Cognitive Science 8 (3): 670-84.

Bruine de Bruin, W. (2005). Save the last dance for me: Unwanted serial position effects on jury evaluations. Acta Psychologica, 118, 245-260.

Bruine de Bruine, W., \& Keren, G. (2003). Order effects on judgments in sequentially judged options due to the direction of comparison. Organizational Behavior and Human Decision Processes, 92, 91-101.

Clingingsmith, D. and Shane, S. (2016). Training Aspiring Entrepreneurs to Pitch Experienced Investors: Evidence from a Field Experiment in the United States. Unpublished Ms.

Danziger, S., Levav J. \& Avnaim-Pesso, L. (2011). "Extraneous Factors in Judicial Decisions," Proceedings of the National Academy of Sciences, 108(17), 6889-6892.

Einav, L., \& Yariv, L. (2006). "What's in a surname? The effects of surname initials on academic success.” The Journal of Economic Perspectives, 20(1):175-188.

Epley, N., and T. Gilovich. 2006. "The Anchoring-and-Adjustment Heuristic: Why the Adjustments Are Insufficient.” Psychological Science 17 (4): 311-18. 
Farr, J. L., York, C. M.. (1975). Amount of Information and Primacy-Recency Effects in Recruitment Decisions. Personnel Psychology, 28, 233-238

Feenberg, D. R., Ganguli, I., Gaule, P., Gruber, J.. (2015). It's Good to be First: Order Bias in Reading and Citing NBER Working Papers. (NBER Working Paper No. 21141). Cambridge, MA: National Bureau of Economic Research.

Flores, R. G., Jr. \& Ginsburgh, V. A. (1996). The Queen Elisabeth musical competition: How fair is the final ranking? The Statistician, 45, 97-104.

Ginsburgh, V., and Van Ours, J. 2003. Expert opinion and compensation: Evidence from a musical competition. The American Economic Review, 93(1): 289-296.

Haque, A. U., \& Ginsparg, P. (2009). "Positional effects on citation and readership in arXiv". Journal of the American Society for Information Science and Technology, 60(11), 22032218.

Houston, D. A., Sherman, S. J., \& Baker, S. M. (1989). The influence of unique features and direction of comparison on preferences. Journal of Experimental Social Psychology, 25, 121-141. Locke, E. A., \& Latham, G. P. (1990). A theory of goal setting and task performance. Englew

Hsu, David H. 2004. “What Do Entrepreneurs Pay for Venture Capital Affiliation?” The Journal of Finance 59 (4): 1805-44.

Huang, W. (2014) “Do ABCs get more citations than XYZ?” Economic Inquiry.

Karlsson, A., Massa, M \& Simonov, A. (2006). "Portfolio Choice and Menu Exposure," working paper available at http://papers.ssrn.com/sol3/papers.cfm?abstract_id=888661 
Kerstholt, J. H., Jackson, J.L.. (1998). Judicial Decision Making: Order of Evidence Presentation and Availability of Background Information. Applied Cognitive Psychology, 12, 445-454

Mantonakis, A., Rodero, P., Lesschaeve, I., \& Hastie, R. (2009). “Order in Choice Effects of Serial Position on Preferences." Psychological Science,20(11), 1309-1312

Maxwell, A., Jeffrey, S., and Levesque, M. 2011. Business Angel Early Stage Decision Making. Journal of Business Venturing, 26: 212-225.

Miller, J. M., \& Krosnick, J. A. (1998). "The impact of candidate name order on election outcomes.” Public Opinion Quarterly, 291-330

Moore, D.A. (1999). “Order effects in preference judgments: Evidence for context dependence in the generation of preferences." Organizational Behavior and Human Decision Processes, 78, 146-165.

Moulton, B. 1990. An Illustration of a Pitfall in Estimating the Effects of Aggregate Variables on Micro Units. The Review of Economics and Statistics, 72: 334-338.

Rose, D. 2014. Angel Investing: The Gust Guide to Making Money and Having Fun Investing in Startups. New York: John Wiley and Sons.

Shah, Priti Pradhan, John P. Bechara, Joseph Kolars, Monica Drefahl, Nicholas LaRusso, Douglas Wood, and Barbara Spurrier. 2014. “Temporal Elements in Career Selection Decisions: An Archival Study Investigating Career Decisions in Medicine.” Organization Science 25 (1): 245-61.

Sudek, R.(2006). Angel investement critieria. Journal of Small Business Strategy, 17(2): 89- 103.

Tversky, A. (1977). Features of similarity. Psychological Review, 84, 327-352. 
Wagner, J. A., \& Klein, N. M.. (2007). Who Wants to Go First? Order Effects within a Series of Competitive Sales Presentations. The Journal of Personal Selling and Sales Management, 27(3), 259-276

Wilson, Vietta E. (1977). “Objectivity and effect of order of appearance in judging of synchronized swimming meets," Perceptual and Motor Skills, 44, 295-298. 